\title{
Review
}

\section{The claims of experience: autobiography and American democracy}

\author{
Nolan Bennett \\ Oxford University Press, New York, 2019, 276 pp., ISBN: 978-0190060695
}

Contemporary Political Theory (2022) 21, S130-S133. https://doi.org/10.1057/s41296021-00492-y; published online 11 May 2021

In the lecture notes of a 1965 course titled 'Political Experiences in the Twentieth Century', Hannah Arendt states, '[w]e look upon [experiences] from the viewpoint of the man upon whom they were raining as it were and who re-acted' (Arendt, 1965). In a similar vein, John Dewey declares that experience is a 'double barreled word' that captures what one does and what one undergoes, what one acts and what one suffers (Dewey, 1929, p. 8). Nolan Bennett's The Claims of Experience: Autobiography and American Democracy is an insightful and original investigation of action and reaction, of doing and undergoing, of possibilities lived and lost as narrated by the actor-sufferers themselves.

Reading the autobiographical writings of five figures at the margins and center of American politics-Benjamin Franklin, Frederick Douglass, Henry Adams, Emma Goldman, and Whittaker Chambers-Bennett persuasively argues that the autobiographical genre is a form of political writing, practice, and claim-making, a 'deliberate act or method of political thinking' (p. 6). Autobiography is a political practice in the sense that it publicizes the authors' lives, bringing them into the space of appearances, as Arendt would say. In this regard, autobiography is not a mere documentary evidence of the life and times of its author. An interpretive reading of life-writing stands to illuminate a constellation of theoretical questions central to democracy in the USA: moral authority, social resistance, racial justice and injustice, the nature and aims of education, and the judgment of oneself and others.

Autobiographies, for Bennett, are also political insofar as their authors push back against 'dominant narratives, against the legal and political manifestations of popular authority that so often stay democratic progress' (p. 8). Bennett develops his arguments by deploying a method of interpretive analysis grounded on what he calls 'claims of experience': a life narrative that 'restores to both author and audience the authority to make meaning of their lives, challenging prevailing authorities and calling to new community' (p. 8). Claims of experience, as I take it, represent at once acts of interpretive resistance and resignifications of the relation

(c) 2021 The Author(s), under exclusive licence to Springer Nature Limited. 1470-8914 Contemporary Political Theory Vol. 21, S3, S130-S133

www.palgrave.com/journals 
between the personal and the political, as well as calls to action and community building.

Bennett's method of analysis in each chapter proceeds in three directions: upward, inward, and outward.

Upwardly, a claim of experience recovers the interpretive authority of the writer over their own life. Regaining this power of self-interpretation, Bennett proposes, is an act of defiance on the part of the autobiographical author against dominant political and/or popular institutions. These institutions had arrogated to themselves the authority to say who the authors 'really' were. With this, their political ideas and the movements or political struggles they are active in-e.g., anarchism and feminism in the case of Goldman, Black liberation in Douglass's example-had been misrepresented

Inwardly, autobiographies are a practice of self-evaluation. While telling their story, the autobiographer grapples with the collective and individual forces through and against which they have become an actor and a political authority of their own.

Finally, a claim of experience travels outward by engaging in a conversation with the reader, inviting them to judge the writer's life in relation to their own, whether in kinship or estrangement. Insofar as the reception of claims of experience is unpredictable, they can succeed or fail, depending 'on those who take them up' (p. 3). If claims of experience are successfully heard, Bennett contends, they may potentially inaugurate a community, a 'we' that partakes in a political vision.

Bennett analyzes these tripartite claim-movements in five chapters. The first chapter, on The Autobiography of Benjamin Franklin, argues that Franklin's claims of experience portray a way of living that he calls 'imperfect independence' (p. 30). Imperfect independence involves an ethics of self-examination and an appeal to the moral and civil improvement of the nation. It also requires reexamining claims made at earlier stages of life. By sharing his claims of experience, Bennett writes, Franklin hoped to become an authoritative guide and ethical inspiration to his readers.

The second chapter moves to Douglass's Narrative of the Life of Frederick Douglass, an American Slave and, more extensively, My Bondage and My Freedom. While Bennet argues that Douglass's first autobiography is a testimony of injustice which invites the reader to judge his claims alongside available criteria of justice, the second is a forceful denunciation and a 'critique of injustice that analyses collective oppression and advocates for communal emancipation' (p. 56). With this, Douglass not only appeals to the reader, but also implicates them in the very structures that make the institution of slavery and racial domination possible at all.

Chapter three is dedicated to The Education of Henry Adams. Bennett proposes that Adams's claim of experience was explicitly pedagogical. In contrast to Franklin's authoritative pedagogy, however, Adams 'sought to diminish his authority over readers', stepping down from his pedestal so that new Americans 
could 'determine how and to what purpose they would reform their own lives' ( $\mathrm{p}$. 84). Moving upward and inward, Adams advocated a model of education which, surpassing appeals to the authority of God or of 'great men', would be grounded in modern science. In turn, 'his outward move insisted that readers draw from him at most his methods of self-inquiry and the scientific theories they produced', and not, as mentioned above, his own conclusions (p. 84).

In chapter four-from my perspective, the most engaging and well-rounded chapter-Bennett reads Emma Goldman's Living My Life. He argues that Goldman's claims of experience and anti-authoritarian politics evolved from an early 'adversarial' approach to one that favors empathy (p. 110). The adversarial approach challenges the authority of individual agents of the state, the market, and the patriarchy, rendering them responsible for violence and oppression. Facing this situation, oppressed peoples must join forces against these figures to liberate themselves. Bennett argues that Goldman eventually realized that this approach risked alienating non-radicals, thus failing to create a shared political consciousness. Seeing that the adversarial approach divided the masses, Goldman shifted to an empathetic approach to anti-authoritarian politics. Instead of ascribing blame to individual authority figures, this new approach points at the institutions and ideologies that prevent class solidarity and emphasizes the political import of care and recognition, both under state structures and beyond them.

In the final chapter, Bennett turns to Whittaker Chambers and his autobiography, Witness. Reading it as a conversion narrative-from Communism to ChristianityBennett contends that Chambers's experience of bearing witness was intended to compel the public to embrace a 'vision of freedom in which the common striving for God would bind America as a nation' (p. 138).

Bennett's book is a successful and compelling call to expand the genres which we, as practitioners of political theory, direct scholarly attention to and from which we theorize. He convincingly demonstrates that autobiography, and the claims of experience it imparts have much to offer to political theory. I fully agree that by failing to incorporate autobiography as a political text, theorists often fall short of grasping the situated and lived dynamic relation between the personal and the political, the private and the public, and the particular and the universal. Life stories thus stand as a fertile hermeneutical soil for theorizing from the ground up and drawing universalizable lessons from micro-histories of oppression, liberation, and community formation.

Bennett writes, 'life writing puts front and center the question of who we are as political theorists to study the world and say what should become of it' (p. 7). This is a very important claim and one that, from my perspective, Bennett could have fleshed out and/or theorized out of his own experience of encountering, reading, and judging the autobiographical texts with which he works. In fact, what is missing here is Bennett's own judgment: were his subjects' claims of experiencewhich are, as he notes, not guaranteed to be heard and always tentative, contingent, 
and contentious - successful from his own perspective as a listener-reader? Finally, given that Bennett's book explores autobiography in relation to American democracy, I missed a comprehensive, comparative, final analysis of the variegated and often divergent claims of experience by his authors as to the meanings of democracy. Also missing is an account of how their understanding of abstract terms, such as democracy, community, authority, oppression, and liberation, is transformed and perhaps enriched when theorized through the lives of others.

\section{References}

Arendt, H. (1965). 'Political Experiences in the Twentieth Century'. Hannah Arendt Papers, Manuscript Division, Library of Congress, Washington, D.C. Subject File: Courses 1949-1975.

Dewey, J. (1929). Experience and nature. London: George Allen and Unwin.

Publisher's Note Springer Nature remains neutral with regard to jurisdictional claims in published maps and institutional affiliations.

Verónica Zebadúa-Yáñez

University of Virginia, Charlottesville, VA 22904, USA

vz2fs@virginia.edu 